\title{
Krim ekstrak kulit delima merah (Punica granatum) menghambat peningkatan jumlah melanin sama efektifnya dengan krim hidrokuinon pada kulit marmut (Cavia porcellus) betina yang dipapar sinar UVB
}

\author{
${ }^{1}$ Eva R. Siahaan \\ ${ }^{2}$ Wimpie Pangkahila \\ ${ }^{3}$ AAGP Wiraguna
}

\author{
${ }^{1}$ Program Pascasarjana Anti-Aging Medicine \\ ${ }^{2}$ Departemen Pasca Sarjana Anti Aging Medicine \\ ${ }^{3}$ Departemen Ilmu Penyakit Kulit dan Kelamin \\ Fakultas Kedokteran Universitas Udayana \\ Email: seanadear34@gmail.com
}

\begin{abstract}
As the outer organ of the body, skin becomes the main target of environmental influences, particularly the UVB rays. Based on analysis of phytochemicals, red pomegranate peel extract contains antioxidants such as flavonoids, phenols, tannins, and vitamin $\mathrm{C}$ which are able to prevent increased skin melanin by inhibiting the actions of tyrosinase. This study was aimed to prove that application of $8 \%$ red pomegranate peel extract (Punica granatum) cream could prevent the increase of skin melanin in female guinea pigs (Cavia porcellus) exposed to UVB as well as to prove that the $8 \%$ red pomegranate peel extract cream was as effective as $4 \%$ hydroquinone cream in preventing increased skin melanin. This was a true experimental study using post test only control group design. Subjects were divided into three groups, with 10 guinea pigs each group. Group 1, the control group, was treated with UVB exposure and basic cream. Group 2 was treated with UVB exposure and $4 \%$ hydroquinone cream. Group 3 was treated with UVB and $8 \%$ red pomegranate peel extract cream. A total of $390 \mathrm{~mJ} / \mathrm{cm} \mathrm{UVB}$ dosage was given for 2 weeks. Histopahtologic slides were stained with Masson-Fontana. The amount of melanin area colored in black was evaluated by the percentage of pixel areas of melanin compared with pixel areas of all epidermal tissues. The results showed that the highest amount of melanin was in group $1(18.13 \pm 4.76 \%)$, followed by group $3(1.876 \pm 0.73 \%)$, and group 2 as the lowest $(0.67 \pm 0.291 \%)$. There was a significant difference between control group and group 2 as s well as group $3(P<0.05)$. There was no significant difference between group 2 and group $3(P$ $>0.05$ ). Conclusion: Application of $8 \%$ red pomegranate peel extract (Punica granatum) cream could prevent the increase of skin melanin in guinea pigs (Cavia porcellus) exposed to UVB. The $8 \%$ red pomegranate peel extract cream was as effective as $4 \%$ hydroquinone cream in preventing increased skin melanin.
\end{abstract}

Keywords: red pomegranate peel extract, melanin, skin, UVB

\begin{abstract}
Abstrak: Sebagai organ terluar dari tubuh, kulit menjadi target utama dari pengaruh lingkungan, terutama oleh sinar UVB. Berdasarkan analisis fitokimia, ekstrak kulit delima merah memiliki kandungan antioksidan seperti flavonoid fenol, tanin, dan vitamin $\mathrm{C}$ yang mampu mencegah peningkatan jumlah melanin dengan cara menghambat kerja enzim tirosinase. Penelitian ini bertujuan untuk membuktikan efek pemberian krim ekstrak kulit delima merah (Punica granatum) $8 \%$ dalam menghambat peningkatan jumlah melanin pada kulit marmut (Cavia porcellus) betina yang dipapar sinar UVB dan krim ekstrak kulit delima merah (Punica granatum) $8 \%$ memiliki efektivitas yang sama dengan krim hidrokuinon $4 \%$ dalam menghambat peningkatan jumlah melanin tersebut. Jenis penelitian ialah eksperimental murni dengan post test only control group design. Subyek penelitian dibagi menjadi tiga kelompok, masing-masing berjumlah 10 ekor marmut betina. Kelompok 1 (kontrol) diberikan pajanan sinar UVB dan krim dasar; kelompok 2 diberikan paparan sinar UVB dan krim hidrokuinon 4\%; dan kelompok 3
\end{abstract}


diberikan pajanan sinar UVB dan krim ekstrak kulit delima merah 8\%. Dosis total UVB 390 $\mathrm{mJ} / \mathrm{cm}^{2}$ yang diberikan selama 2 minggu. Sediaan histopatologik jaringan kulit menggunakan pewarnaan Masson-Fontana. Jumlah melanin dihitung dengan persentase pixel luas area melanin dibandingkan pixel seluruh jaringan epidermis. Hasil penelitian menunjukkan bahwa jumlah melanin paling tinggi terdapat pada kelompok $1(18,13 \pm 4,76 \%)$, diikuti kelompok 3 $(1,876 \pm 0,73 \%)$, dan paling rendah pada kelompok $2(0,67 \pm 0,291 \%)$. Terdapat perbedaan bermakna antara kelompok 1 dengan kelompok 2 dan $3(P<0,05)$ sedangkan antara kelompok 2 dan 3 tidak berbeda bermakna dalam mencegah peningkatan jumlah melanin $(P>0,05)$. Simpulan: Krim ekstrak kulit delima merah (Punica granatum) $8 \%$ dapat menghambat peningkatan jumlah melanin pada kulit marmut (Cavia porcellus) betina. Krim ekstrak kulit delima merah (Punica granatum) $8 \%$ sama efektif dengan krim hidrokuinon $4 \%$ dalam menghambat peningkatan jumlah melanin pada kulit marmut.

Kata kunci: kulit delima merah, melanin, kulit, UVB, marmut betina.

Penuaan (aging) merupakan proses alami yang pasti dialami oleh setiap makhluk hidup di dunia ini. Pada penuaan didapatkan menghilangnya kemampuan jaringan secara perlahan untuk memperbaiki diri serta mempertahankan struktur dan fungsinya. Penuaan terjadi secara bertahap sehingga dapat dilakukan cara untuk menghambat proses penuaan tersebut. Banyak faktor yang menyebabkan terjadinya proses penuaan yaitu faktor internal seperti radikal bebas, berkurangnya hormon, apoptosis, genetik, dan sistem kekebalan tubuh yang menurun sedangkan faktor eksternal yaitu diet tidak sehat, gaya hidup tidak sehat, polusi, stres dan kemiskinan. Jika faktor tersebut dapat dihindari, maka dengan sendirinya proses penuaan dapat dihambat dan kualitas hidup dapat dipertahankan. ${ }^{1}$

Indonesia merupakan negara tropis yang disinari matahari sepanjang tahun. Sinar UV memberikan kontribusi $80 \%$ penyebab penuaan kulit. Paparan sinar UV yang terjadi secara terus menerus dapat menyebabkan flek atau pigmentasi seperti lentigo dan melasma. Sinar UV terbagi atas 3 spektrum, yaitu: UVA $(320-400 \mathrm{~nm})$, UVB (290-320 nm), dan UVC (270-290 nm). Sinar UVB memberikan efek lebih banyak dari pada UVA dalam menstimulasi pigmentasi kulit. ${ }^{2}$ Efek sinar UV yang bersifat akut akan menyebabkan eritema, pigmentasi, kerusakan DNA, dan penekanan sistem imun sedangkan efek sinar UV yang bersifat kronis akan menyebabkan photoaging dan fotokarsinogenesis.
Melanosit menghasilkan melanin yang berfungsi sebagai pelindung kulit terhadap kerusakan akibat paparan sinar UV dan penahan radikal bebas. Paparan sinar UV yang berlebihan dan terus-menerus akan menyebabkan kerusakan protein, lipid, asam nukleat sehingga menghasilkan radikal bebas yang akan merusak sel-sel lainnya. ${ }^{3}$ Terdapat 2 tipe melanin yaitu eumelanin (pigmen berwarna coklat kehitaman) dan pheomelanin (pigmen berwarna kuningkemerahan). Pembentukan melanin dapat dicegah dengan cara menghambat kerja enzim tirosinase, transfer tirosinase, dan aktifitas tirosinase. Krim pemutih kulit (penghambat hiperpigmentasi) yang bekerja sebagai inhibitor tirosinase telah banyak ditemukan dalam bahan kosmetik, di antaranya ialah asam askorbat, arbutin, asam kojik, dan hidrokuinon. ${ }^{4}$

Warna kulit manusia tergantung pada jumlah, ukuran, jenis, dan distribusi partikel sitoplasma yang disebut melanosom (mengandung biochrome coklat yaitu melanin). Melanogenesis dipengaruhi oleh banyak faktor yaitu sinar UV, usia (jumlah melanosit akan berkurang), hormon, proses inflamasi pada kulit (menstimulasi keratinosit, melanosit, dan sel-sel inflamasi lainnya), obat-obatan (antibiotik, sulfonamid, dan tetrasiklin), beberapa jenis diuretik, kontrasepsi oral, nonsteroidal antiinflammatory drugs) (NSAID), dan obat-obat psikosis.

Kulit delima merah telah banyak digunakan sebagai pengobatan tradisional di berbagai negara. Delima merah 
mengandung polifenol kuat seperti flavonoid dan tanin yang terhidrolisis (punicalin, pedunculagin, punicalagin, gallic acid dan ellagic acid), yang telah terbukti khasiatnya sebagai anti inflamasi, antioksidan, dan anti kanker dalam banyak penelitian in vivo dan in vitro. ${ }^{4}$ Cara kerja delima merah dalam mencerahkan kulit ialah dengan menghambat proliferasi melanosit dan sintesis melanin oleh tirosinase di melanosit. ${ }^{5}$

Kulit buah delima merah mengandung 20-30\% ellagitannin dan telah diteliti sebagai antioksidan yang kuat. Punicalagin ialah salah satu bentuk antioksidan ellagitannin (polifenol) yang terdapat dalam buah delima merah selain ellagic acid, gallic acid, dan antosianin. Dua kandungan polifenol pada sari buah delima merah yang terbanyak ialah punicalagin dan ellagitannin. Punicalagin merupakan antioksidan poten yang dimetabolisme menjadi ellagic acid dan urolitin yang juga merupakan antioksidan poten. Ellagitannin merupakan tanin yang terhidrolisis.

Ellagic acid merupakan bentuk terhidrolisis dari ellagitannin yang merupakan komponen antioksidan terbesar dari buah delima merah. Telah diteliti bahwa kandungan ellagic acid memiliki afinitas tinggi terhadap tembaga yang merupakan bagian aktif dari tirosinase, sehingga bekerja dengan menghambat aktivitas ikatan pada tembaga. ${ }^{7}$ Pada penelitian terbaru, telah dievaluasi bahwa ellagic acid pada ekstrak delima merah memiliki efek proteksi dan perbaikan terhadap pigmentasi kulit yang dipajan sinar UV yang diberikan secara oral pada marmut. ${ }^{5}$

Hidrokuinon efektif sebagai bahan pemutih kulit dalam jangka waktu pendek dan konsentrasi yang rendah sekitar 0,01 $\mathrm{mM}$ hidrokuinon mampu menghambat kerja tirosinase sampai aktivitasnya hampir mencapai nilai nol. ${ }^{8}$ Walaupun sudah terbukti efektif sebagai senyawa yang dapat menghambat kerja tirosinase, hidrokuinon mempunyai efek negatif yaitu merusak kemampuan hidup sel, menghambat sintesis DNA dan RNA, degradasi melanosom dan penghancuran melanosit. ${ }^{9}$

Mengingat efek samping akibat pemakaian hidrokuinon tersebut maka peneliti tertarik untuk mengetahui manfaat buah delima merah yang mengandung tanin dapat berfungsi sebagai antioksidan dalam mencegah kerusakan oksidatif DNA dan sebagai antitirosinase yang dapat menghambat proses biosintesis melanin sehingga peningkatan produksi melanin tidak terjadi setelah pajanan sinar UVB. ${ }^{7}$

\section{METODE PENELITIAN}

Jenis penelitian ini ialah eksperimental murni dengan menggunakan post test only control group design. ${ }^{10}$ Subyek penelitian ialah 30 marmut betina, berumur 3 bulan, dengan berat badan 300-350 gr dibagi menjadi 3 kelompok, masing-masing berjumlah 10 ekor marmut. Kelompok 1 ialah kelompok kontrol, diberikan pajanan sinar UVB dan krim dasar; kelompok 2 diberikan pajanan sinar UVB dan krim hidrokuinon 4\%; dan kelompok 3 diberikan pajanan sinar UVB dan krim ekstrak kulit delima merah $8 \%$. Dosis total UVB yaitu $390 \mathrm{~mJ} / \mathrm{cm}^{2}$ yang diberikan selama 2 minggu. Pemeriksaan histopatologik dari jaringan kulit menggunakan pewarnaan Masson-Fontana. Jumlah melanin dihitung dengan persentase pixel luas area melanin dibandingkan dengan pixel seluruh jaringan epidermis.

\section{HASIL DAN BAHASAN}

Hasil penelitian menunjukkan bahwa jumlah melanin paling tinggi terdapat pada kelompok 1 (kontrol) sebesar 18,13 $\pm 4,76 \%$. Jumlah melanin paling rendah terdapat pada kelompok 2 (krim hidrokuinon 4\%) sebesar $0,67 \pm 0,291 \%$, sedangkan jumlah melanin pada kelompok 3 (krim ekstrak kulit delima merah $8 \%$ ) sebesar 1,876 $\pm 0,73 \%$ (Gambar 1). Terdapat perbedaan bermakna antara kelompok 1 dengan kelompok 2 dan 3 ( $P$ $<0,05)$. Perbandingan antara kelompok 2 dan 3 tidak berbeda bermakna dalam mencegah peningkatan jumlah melanin $(P$ $>0,05)$ (Tabel 1).

Pemeriksaan histopatologik dilakukan setelah 2 minggu perlakuan dengan biopsi 
jaringan kulit punggung marmut. Pada pewarnaan Masson-Fontana melanin akan terlihat berwarna hitam. Gambaran melanin pada jaringan histopatologik epidermis kulit marmut disajikan pada Gambar 2A, $\mathrm{B}$, dan $\mathrm{C}$ (panah menunjukkan melanin).

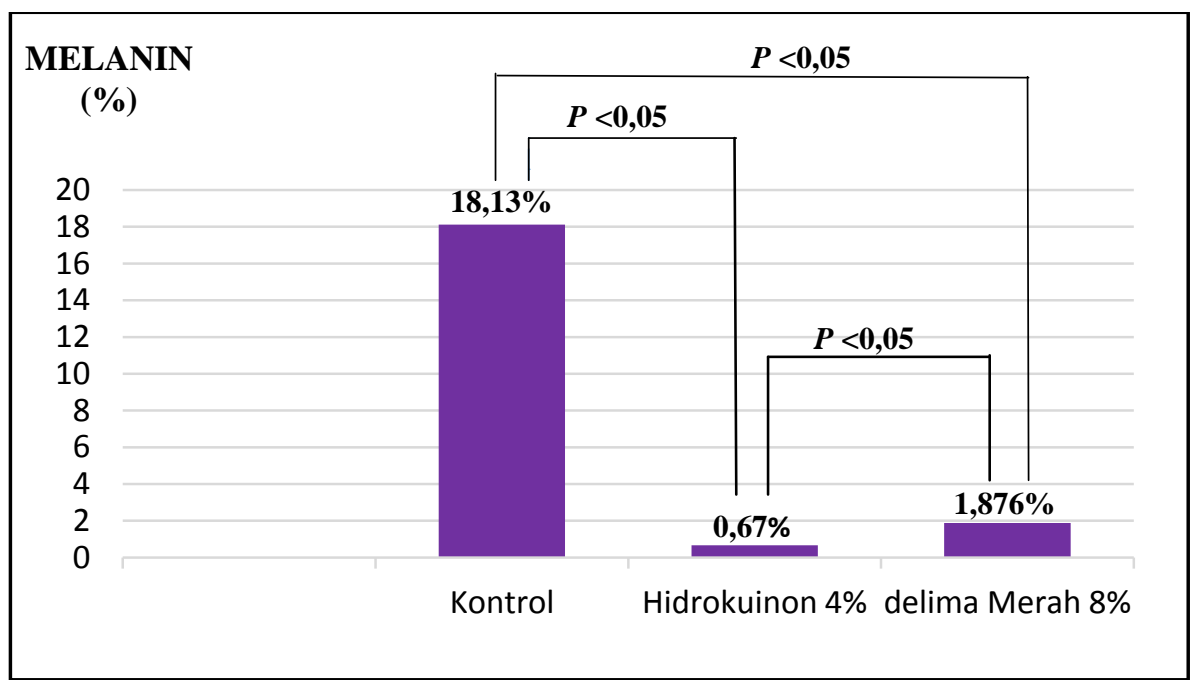

Gambar 1. Perbandingan jumlah melanin antar kelompok

Tabel 1. Perbedaan jumlah melanin antar kelompok setelah perlakuan

\begin{tabular}{cccccc}
\hline $\begin{array}{c}\text { Kelompok } \\
\text { subyek }\end{array}$ & $\begin{array}{c}\text { Jumlah } \\
\text { subyek } \\
(\mathbf{n})\end{array}$ & $\begin{array}{c}\text { Jumlah } \\
\text { melanin } \\
(\boldsymbol{\%})\end{array}$ & $\begin{array}{c}\text { Simpangan } \\
\text { Baku (SB) }\end{array}$ & $\begin{array}{c}\text { Distribusi } \\
(\mathbf{F})\end{array}$ & $\begin{array}{c}\text { Signifikansi } \\
(\boldsymbol{P})\end{array}$ \\
\hline Kelompok 1 & 10 & $18,13^{\mathrm{a}}$ & 4,76 & & \\
Kelompok 2 & 10 & $0,67^{\mathrm{b}}$ & 0,291 & 122,634 & 0,000 \\
Kelompok 3 & 10 & $1,876^{\mathrm{c}}$ & 0,73 & & \\
\hline
\end{tabular}

NB: notasi $(\mathrm{a}, \mathrm{b}, \mathrm{c})$ yang berbeda menunjukkan berbeda bermakna $(P<0.05)$; notasi yang tidak berbeda menunjukkan tidak berbeda bermakna $(P>0,05)$ diuji menggunakan LSD test

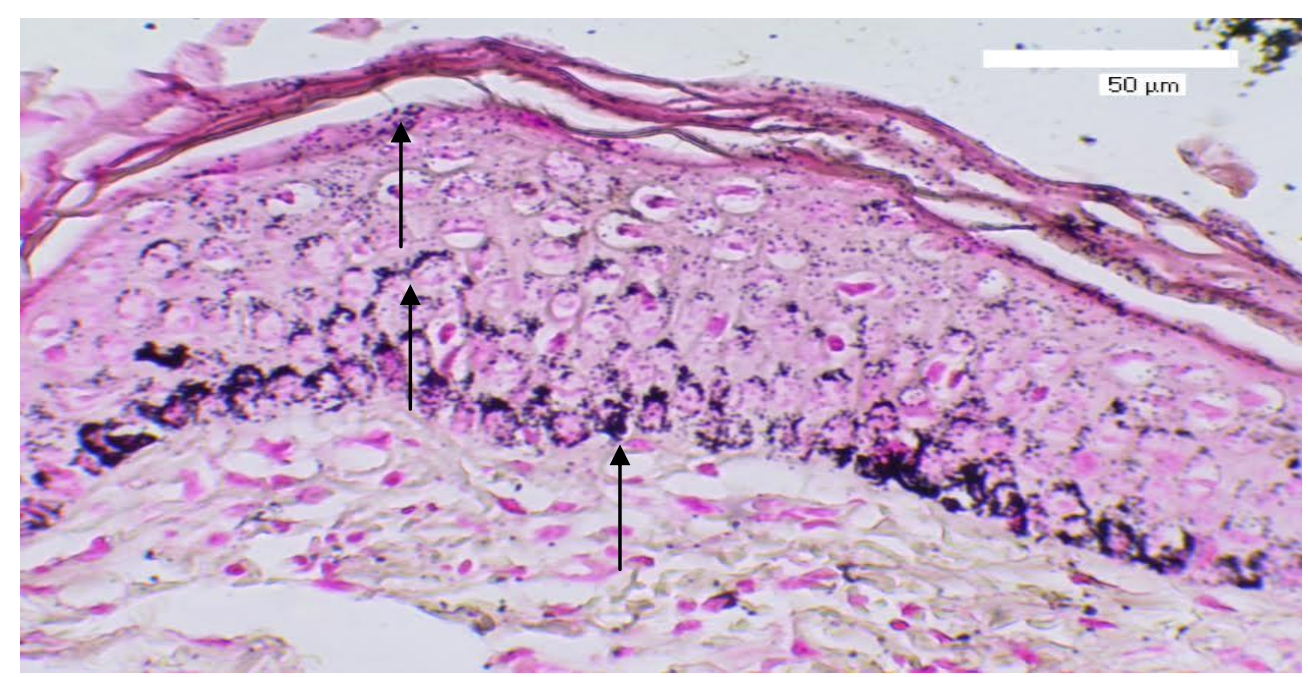

Gambar 2A. Histopatologik melanin kelompok kontrol. Terlihat kumpulan melanin (berwarna hitam) yang padat berkelompok memenuhi stratum korneum dan stratum basal epidermis 


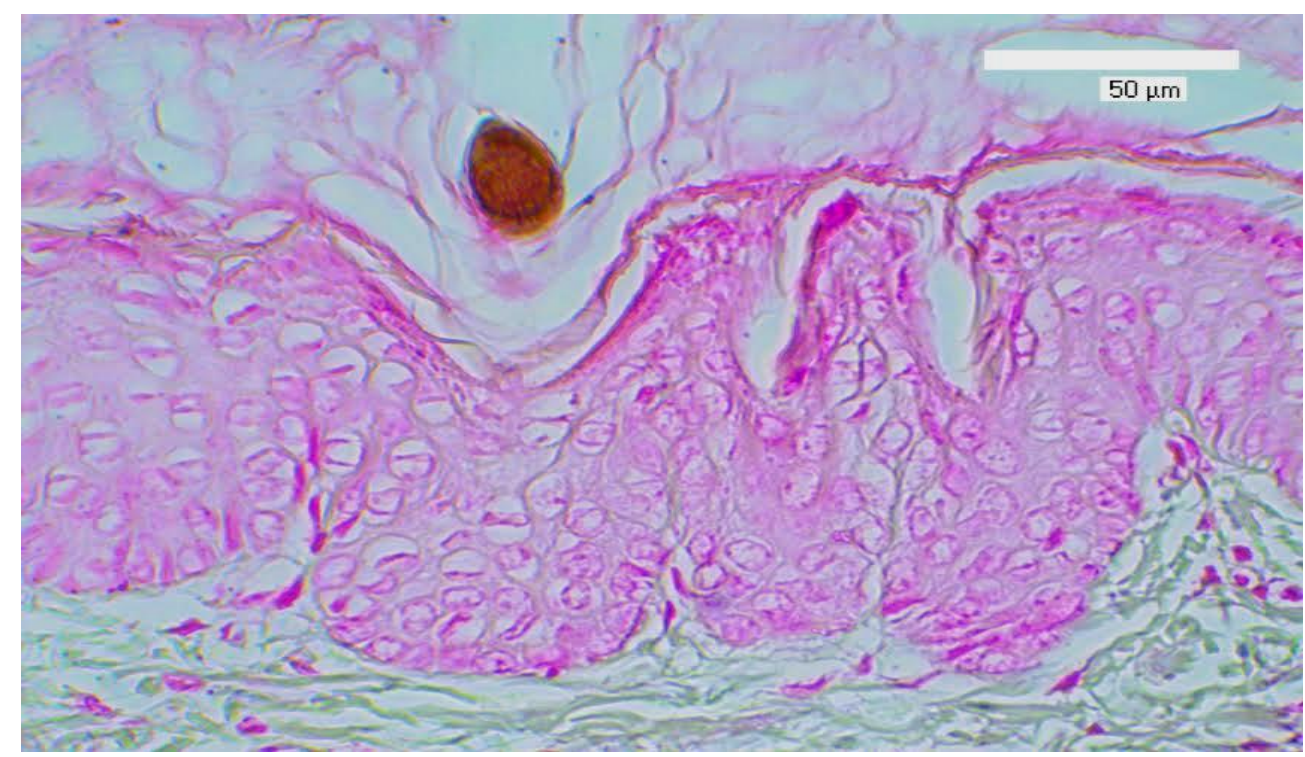

Gambar 2B. Histopatologik melanin kelompok 2 (krim hidrokuinon 4\%). Tidak terlihat melanin (berwarna hitam) di stratum korneum dan stratum basal epidermis

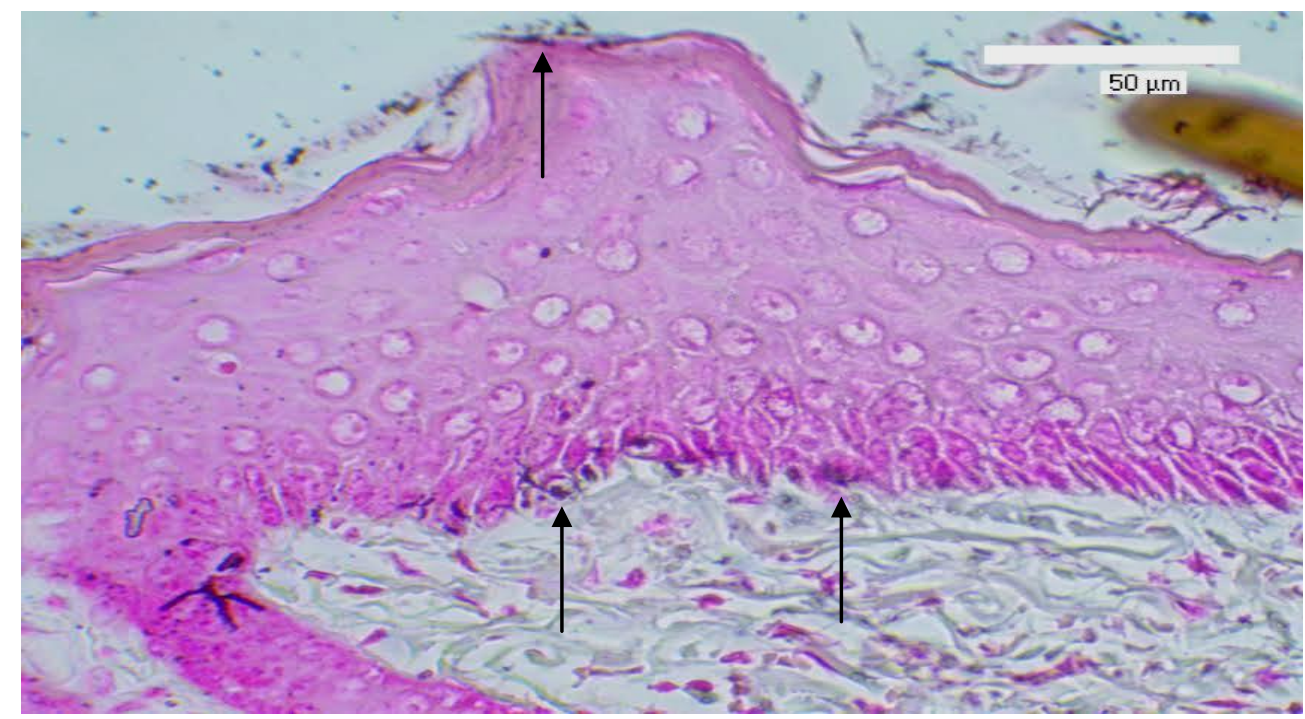

Gambar 2C. Histopatologik melanin kelompok 3 (krim delima merah 8\%). Terlihat melanin (berwarna hitam) sedikit berkelompok di stratum basal epidermis dan sedikit menyebar di stratum korneum epidermis

Hasil penelitian ini terkait dengan kandungan ekstrak kulit delima merah (Punica granatum) yang dianalisis di UPT Laboratorium Analitik Universitas Udayana mengandung flavonoid 1148,52 mg/100gr QE, fenol 326,92 mg/100gr GAE, tannin 34182,62 mg/100gr TAE, vitamin C 9363,39 $\mathrm{mg} / 100 \mathrm{gr}$ dan antioksidan 132446,25 mg/100gr GAEAC.

Mekanisme kerja delima merah yang mengandung antioksidan seperti flavonoid, fenol, tanin dan vitamin c disajikan pada gambar 3. Flavonoid merupakan komponen polyphenolic flavonoid turunan benzopyrane yang memiliki cincin fenol dan pyrane, terdapat pada banyak tanaman. Berdasarkan struktur kimia, lebih dari 4000 flavonoid telah diidentifikasikan dari berbagai tanaman. Efek perlindungan flavonoid dalam sistem biologik ialah kapasitasnya untuk mentransfer elektron kepada radikal bebas, mengikat katalis 
logam, mengaktifkan antioksidan enzimatik, dan menghambat oksidase. Pada lapisan epidermis sinar UVB dapat menghasilkan ROS terutama dari proses lipid peroksidase membran keratinosit dan melanosit. Flavonoid dapat berfungsi sebagai antioksidan untuk menangkal radikal bebas ini, sehingga proses melanogenesis yang dipicu oleh adanya ROS dapat dihambat dan dinetralisir. ${ }^{12}$

Tanin adalah senyawa fenol yang memiliki berat molekul 500-3000 daltons (DA). Tanin diklasifikasikan atas 2 jenis: tanin terhidrolisis (hydrolyzable tannin) yaitu tanin pada pemanasan dengan asam klorida atau asam sulfat menghasilkan asam galat (ellagic acid), dan tanin terkondensasi (condensed tannin) yaitu tanin pada pemanasan asam klorida menghasilkan phlobaphenes seperti phloroglucinol. Tanin memiliki sifat larut dalam air dan alkohol karena tanin banyak mengandung fenol yang memiliki gugus $\mathrm{OH}$. Tanin dapat mencegah kerusakan oksidatif DNA melalui dua cara, yaitu mengikat logam terutama besi dan secara langsung menangkal radikal bebas. Tanin juga mempunyai kemampuan sebagai anti tirosinase karena menghambat proses biosintesis melanin sehingga peningkatan produksi melanin tidak terjadi setelah paparan sinar UVB (Gambar 3). ${ }^{7}$

TANIN (Menghambat kerja enzim tirosinase)

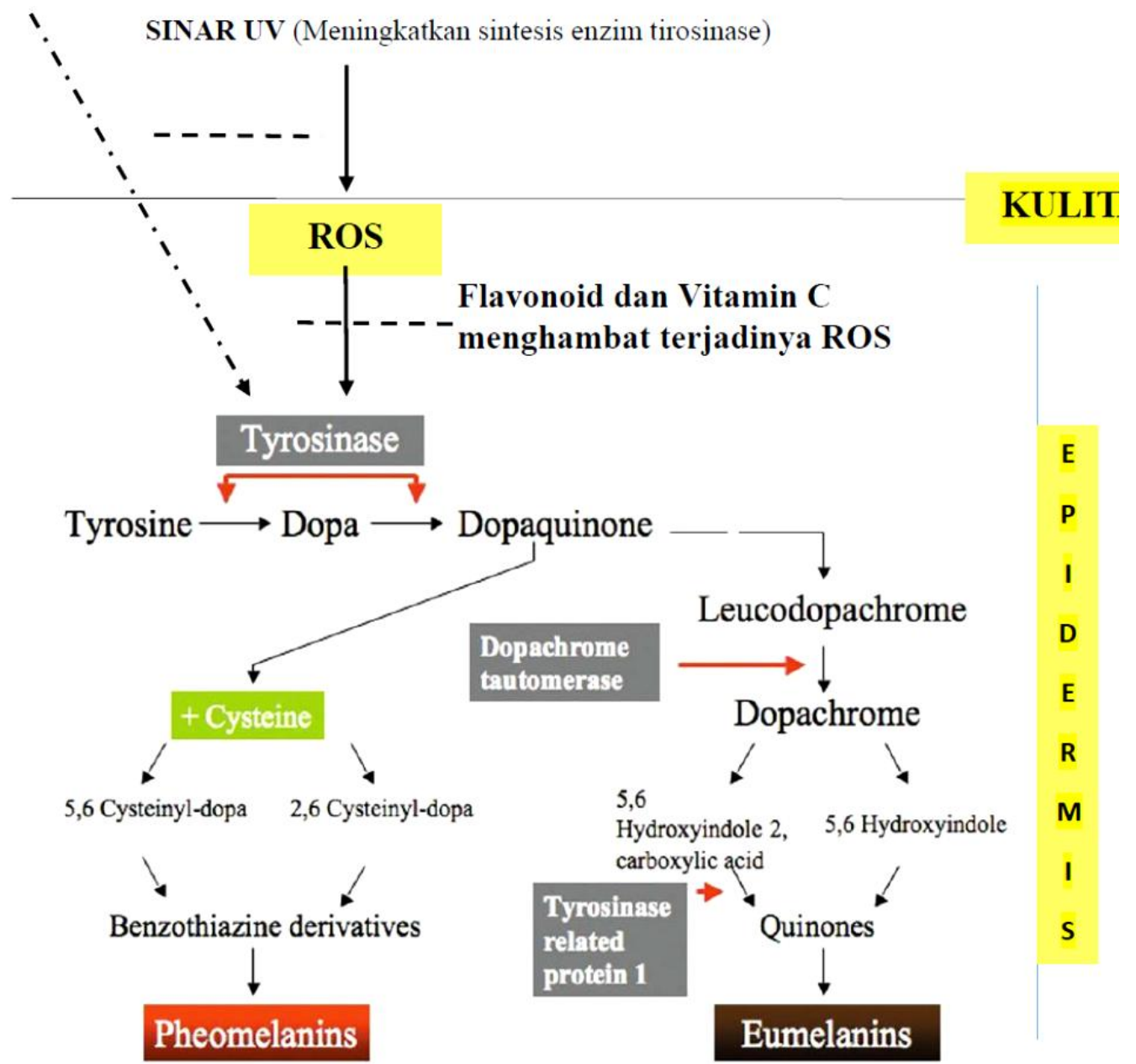

Gambar 3. Mekanisme tanin, flavonoid, dan vitamin C dalam menghambat kerja enzim tirosinase. ${ }^{11}$ Keterangan: Kedua melanin, eumelanin dan pheomelanin berasal dari asam amino tirosin. Tirosinase merupakan enzim yang mengkatalisis terjadinya kedua melanin tersebut. Bila kerja enzim tirosinase dihambat maka sintesis melanin tidak terjadi. 
Vitamin $\mathrm{C}$ merupakan antioksidan
primer yang bekerja dengan cara menetralisir radikal bebas dengan mendonasi 1 elektronnya. Berkat efek vitamin $\mathrm{C}$ tersebut maka ROS tidak terbentuk dan proses melanogenesis dapat dihambat, sehingga tidak terjadi peningkatan jumlah melanin. Cara kerja vitamin $\mathrm{C}$ dalam menghambat peningkatan jumlah melanin yaitu dengan menurunkan oksidasi melanin dan mencegah DOPAkuinon kembali menjadi DOPA. ${ }^{12}$

Ekstrak kulit delima merah terbukti dapat mencegah peningkatan jumlah melanin pada kulit marmut betina yang dipapar sinar UVB. Hal ini dikarenakan ekstrak kulit delima merah mengandung beberapa senyawa seperti tanin, flavonoid, dan vitamin $C$ yang mempunyai efek sebagai antioksidan dan fotoprotektif degradasi tirosinase sehingga mencegah peningkatan jumlah melanin.

\section{SIMPULAN}

Berdasarkan hasil penelitian dan bahasan dapat disimpulkan bahwa pemberian krim ekstrak kulit delima merah (Punica granatum) 8\% dapat menghambat peningkatan jumlah melanin pada kulit marmut (Cavia porcellus) betina. Krim ekstrak kulit delima merah (Punica granatum) $8 \%$ sama efektif dengan krim hidrokuinon $4 \%$ dalam menghambat peningkatan jumlah melanin pada kulit marmut (Cavia porcellus) betina yang dipapar sinar UVB.

\section{DAFTAR PUSTAKA}

1. Pangkahila, W. Anti Aging Medicine (1st ed). Jakarta: Kompas, 2007; p 1-52.

2. Alam M, Havey J. Photoaging. In: Draelos ZD, editor. Cosmetic Dermatology Products and Procedures. New Jersey: Wiley-Blackwell, 2010; p. 13-20.

3. Pillai S, Cornell M, Oresajo C. Skin physiology pertinent to cosmetic dermatology. In: Draelos ZD, editor. Cosmetic Dermatology Products and
Procedures (1st ed). New Jersey: Wiley-Blackwell, 2010; p 3-11.

4. Pacheco-Palencia LA, Giuliana N, Lal H, Stephen TT, Susanne U. Protective effects of standardized pomegranate (Punica granatum L.) polyphenolic extract in ultraviolet-irradiated human skin fibroblasts. J Agric Food Chem. 2008;56(18):8434-41.

5. Yoshimura M, Watanabe Y, Kasai K, Yamakoshi J, Koga T. Inhibitory effect of ellagic acid-richh pomegranate extract on tyrosinase activity and ultraviolet induced pigmentation. J Biosci Biotechnol Biochem. 2005;69:2368-73.

6. Singh RP, Chidambara Murthy KN, Jayaprakasha GK. Studies on the antioxidant activity of pomegranate (Punica granatum) peel and seed extracts using in vitro models. J Agric Food Chem. 2002;50:81-6.

7. Shimogaki H, Tanaka Y, Tamai H, Masuda M. In vitro and vivo evaluation of ellagic acid on melanogenesis inhibition. Int $\mathrm{J}$ Cosmet Sci. 2000;22:291-303.

8. Westerhof W, Kooyers T. Hydroquinone and its analogues in dermatology-a potential health risk. J Cosmet Dermatol. 2005;4(2):55-9.

9. Perez BA, Perez MMA, Camacho F. Management of facial hyperpigmentation. Am J Clin Dermatol. 2000;1(5):261-8.

10. Marczyk GR, Dematteo D, Festinger D. Experimental design. In: DeMatteo D, editor. Essential of Research Design and Methodology (1st ed). New Jersey: John-Wiley, 2005; p. 48-56.

11. Chang TS. An update review of tyrosinase inhibitors. 2009. [cited 2014 May 21]. Available from: http://www.ncbi.nlm.nih.gov/pmc/articl es/PMC2705500/

12. Yu J, Wang L, Walzem RL, Miller EG, Pike LM, Patil BS. Antioxidant activity of citrus limonoids, flavonoids and coumarins. J Agric Food Chem. 2005;53:2009-14. 